\title{
Motivation of Colorado ranchers with federal grazing allot-
} ments

\author{
E.T. BARTLETT, R.G. TAYLOR, J.R. MCKEAN, AND J.G. HOF
}

\section{Abatract}

Net returns to investment on western ranches are often low or negative. Ranchers who graze cattle on federal range during the summer in Colorado were ampled to determine their willingeses to sell their ranches and to determine which factors were important in their decision to ranch. Cluster analyeis was used to classify the ranchers into 4 groups. Willingness to sell the ranch was the most important factor in claseifying groups. Approximately 75\% of the federal permittees would not condider selling their ranches in the current market while over half responded that rate of return on investment was of little or no importance in their decision to be in the cattle business. The groups also differed with respect to the importance of being near family and friends, and labor and aseet mobility.

\section{Key Worda: public lands, rancher behavior}

Net returns to capital and management in western range livestock operations are often low or negative. This fact has prompted some economists to view a ranch as a consumption good to some degree rather than a pure production enterprise (Smith and Martin 1972). Consumptive components such as the value of a rural lifestyle or a land ethic could raise ranch prices beyond that which economic returns from livestock would justify. The degree to which these consumption attributes dominate ranch decisions will vary with the values of individual ranchers.

The purpose of this paper is to determine what motivates ranchers to stay in ranching. We grouped ranchers based on the importance they placed on various attributes including their willingness to sell their ranches. The results apply to ranchers using forage from federal land during the summer of 1983 in Colorado.

The research reported here was part of a study that applied the contingent valuation method to estimate the demand for summer forage from federal land in Colorado (McKean et al. 1986). Therefore, Colorado ranchers not using federal forage were not included in the population. Social parameters were measured and related to demand for forage.

\section{Methods}

A mail survey was used to elicit attitudes from a sample of ranchers. The questionnaire included Smith and Martin's questions defining "land fundamentalism" as a starting point (Smith 1971). Smith defined land fundamentalism as "the attitude that a greater amount of satisfaction can be received from associating directly with the physical environment than with the 'man-made'." Discussion with Rogers' aided the design of the social parameter questions. We concluded that we should reduce the redundancy in the "Land or Rural" preference questions that Smith and Martin

\footnotetext{
Authors are professor and research associate, Department of Range Science, professor, Department of Agricultural and Natural Resource Economics, Colorado State University, Ft. Collins 80523; and principal economist, Rocky Mountain Forest and Range Experiment Station, USDA Foreat Service, Ft. Collins, Colo. 80525.

Research was funded under Cooperative Agreement RM80-143-CA between USDA Foreat Service and Colorado State Univeraity with funding from Colorado State University Agricultural Experiment Station (Project CO-191). The usual disclaimer applies.

Manuscript accepted 24 April 1989.
}

Rosers. D. 1983. Personal communication. Formerly professor and department head, Dept. of Sociology, Colorado State University. found significant, that we should implement questions on social and family ties, and that we should construct questions on perceived mobility of resources outside ranching.

The contingent market constructed in the questionnaire was specific to summer grazing for cattle. Because we had reason to believe that other seasons would each have a unique demand, and grazing for sheep also represents a different demand, those grazing markets were explicitly excluded. The sample was a simple random sample of the 1,530 ranchers who had summer federal grazing permits in Colorado in 1983, and who had cattle.

Survey sampling and questionnaire design included a presurvey which had several functions. Foremost among those functions was to see if the population of ranchers in Colorado understood and responded well to the questionnaire format and questions. The second function of the pre-survey was to estimate response variance and response rate to determine the required sample size. The Water Resources Council (WRC)(1979) recommends a pre-survey sample of at least 200 . We selected and mailed to a random sample of 238 ranchers to test the contingent valuation questions. As a result of the presurvey, the survey was shortened considerably and some of the questions were made more explicit. However, questions used in this study were unchanged in the final questionnaire. One thousand ranchers were sent the improved questionnaire with one additional mailing to nonrespondents. For the questions used in this study, we pooled the presurvey and survey responses. Of the 1,238 questionnaires mailed, a total of 351 questionnaires of which 313 were useable in this study were returned. The low response rate was at least partly due to the nature of the study to determine forage value. Comments of respondents indicated that ranchers may have not responded because they felt the questionnaire or study was a threat to them. The possibility of non-response bias cannot be ruled out, but, at the very least, the results apply to one-fifth of the population.

Seven variables relating to continuing in ranching were examined in the survey. The variables were defined as: (1) desire to sell ranch (WOULD SELL), (2) strength of land ethic (LAND ETHIC), (3) quality of family life (FAMILY LIFE), (4) strength of social ties (SOCIAL TIES), (5) importance placed on mobility of the rancher's labor (LABOR MOBILITY), (6) importance placed on difficulty of sale of ranch assets (ASSET MOBILITY), and (7) importance of investment return (PROFIT MOTIVE). The respondent rated variables on a scale of 1 (highly important) to 4 (not important) except the "desire to sell the ranch" question which simply elicited a "yes" or "no" response.

Based on Smith and Martin's work, a simple correlation analysis did not appear to promise to identify relationships between rancher attitudes and the desire to be in ranching. Therefore, cluster analysis was used to determine sets of attitudes that affect whether a rancher is willing to sell or not. Cluster analysis is a technique that separates respondents into groups based upon similarity of responses to a specified set of variables. The BMDP routine used was a K-mean clustering - nonhierarchical technique designed to group cases, not variables, for large amounts of data (Dixon 1981). Nonhierarchical clustering was chosen because the initial partition of groups can be set by the researcher instead of 
building a hierarchy from the most similar individuals in the sample (Johnson and Wichern 1982).

To make this analysis more statistically meaningful, the survey data were divided by their standard deviations. This procedure had two effects on the composition of the final cluster groups. The first effect was to standardize variables that were measured in different units. This was desired because the WOULD SELL question was measured on a 0-1 scale, and the remainder of the questions on a scale of 1 to 4 . A second effect from this procedure accounted for the different distributions of the responses for each variable. For example, a large proportion of the ranchers believed "quality of ranch-family life" to be of high importance, whereas the importance of investment return was much more dispersed. The standard deviation with the former would be very low, and with the latter, very high. By dividing the survey data by their standard deviations, the family-life variable was weighted relatively more because its standard deviation was so low. Conversely, the relative importance of the investment-return variable was decreased with its higher standard deviation. If a given rancher does not feel, as the overwhelming majority do, that family life on a ranch is important, that dissenting opinion was weighted more heavily by the standardization procedure. Thus, in those questions that obtained a majority of responses in the "high" or the "none" categories, the dissenting opinions were given more importance through the standardization process.

Cluster analysis can be used as an explanatory or descriptive technique to point out associations of variables that form natural groups. To utilize the results of clustering, judgment concerning the level of clustering that best describes a consistent picture of rancher behavior was necessary. The goal was to utilize the fewest possible groups without obscuring associations. To accomplish this objective, the clustering routine was run for 2,3 , and 4 , and arbitrarily up to 8 clusters.

\section{Results and Discussion}

Even a visual examination of the social and lifestyle variables revealed a great deal about rancher behavior. Approximately $75 \%$ of federal permittees in Colorado would not consider selling their ranches in the current market. Smith and Martin (1972) identified the desire to hold ranch properties as the principal reason for an historic acceptance of low return rates on ranchland investment. This conclusion is supported in our study, with over half of the ranchers responding that rate of return on investment was of little or no importance (Fig. 1).

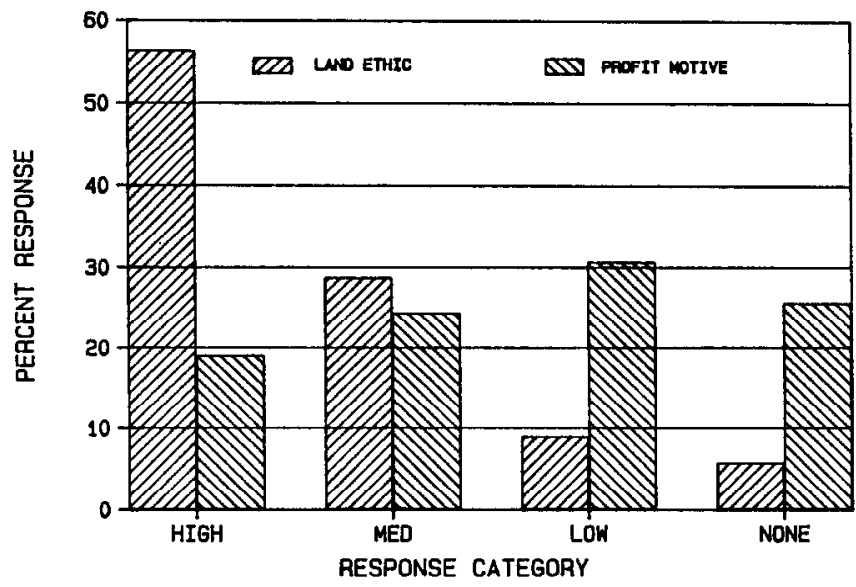

Fis. 1. Percentage of ranchers' responses to the questions of "owning a ranch allows me to feel closer to the earth" (LAND ETHIC) and "obtaining a good return in investment" (PROFIT MOTIVE). (A "none" response indicates no importance.)
Some reasons for profit being assigned little importance can be found in the importance rankings of the lifestyle variables. $A$ majority (56\%) of ranchers assigned a high importance to a land ethic (Fig. 1), and 70\% highly valued family life on the ranch (Fig. 2).

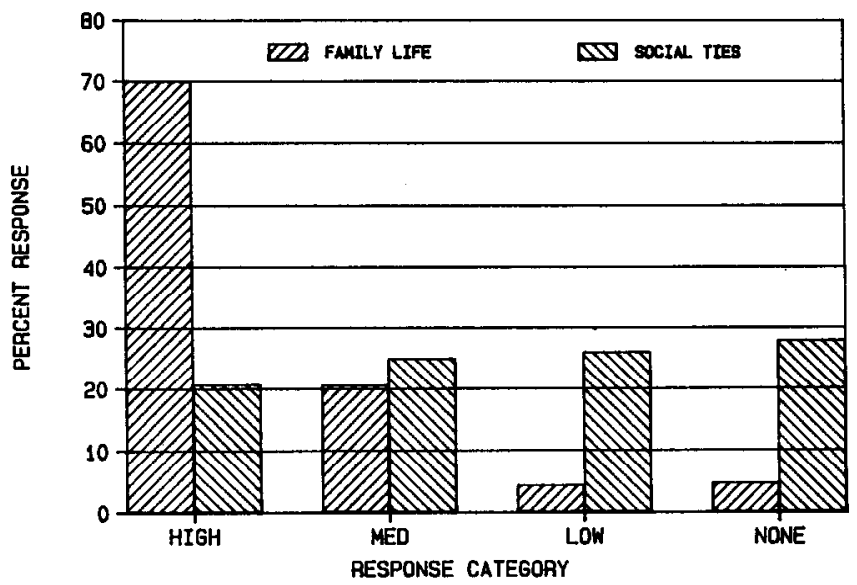

Fig. 2. Percentage of ranchers' responses to the questions of "quality of family life on a ranch" (FAMILY LIFE) and "strength of social ties to friends and relatives on a ranch" (SOCIAL TIES). (A "none" response indicates no importance.)

In addition to the social attitudes of ranchers, there are also constraints on rancher behavior. About $40 \%$ of ranchers said that it would be difficult to find an alternative job. Also, $50 \%$ felt that the difficulty in selling their ranch was an important reason to continue ranching (Fig. 3).

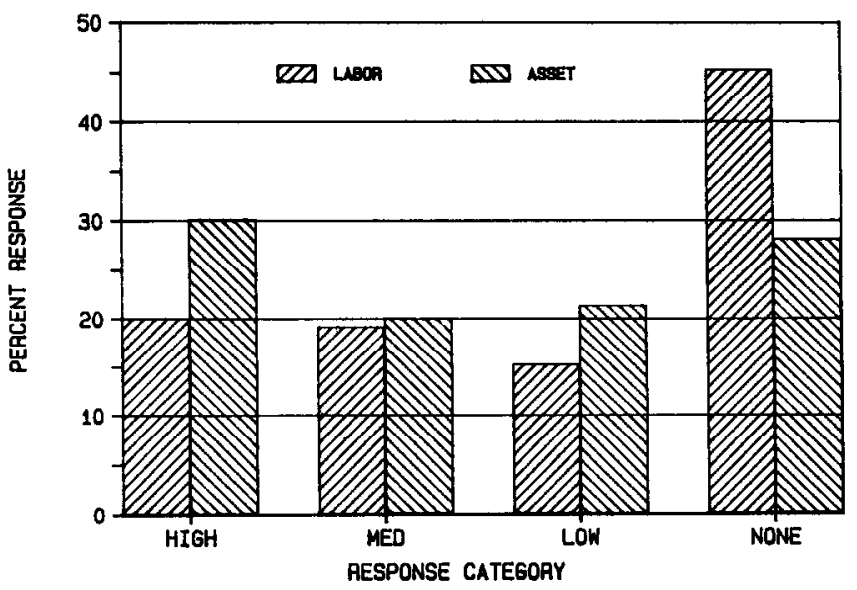

Fis. 3. Percentage of ranchers' responses to the questions of "difficulty of obtaining a job outside the ranch" (LABOR MOBILITY) and "difficulty of selling the ranch in the current market" (ASSET MOBILITY). (A "none" response indicates no importance.)

With cluster analysis, 4 groups provide traits observable in real-world rancher behavior. At greater than 4 clusters, the additional clusters did not increase clarification. For 2 or 3 clusters, coherent aggregate behavior was not discernible. Thus, ranchers in the sample were classified into one of four groups. The summary statistics of the clustering are given in Table 1 and Figure 4.

Certain variables were more important in differentiating the cluster groups than others. Because response to the SELL RANCH question may be related to many other variables as Smith and Martin suggested, it is not surprising that the desire to sell one's ranch was the most significant variable in placement of ranchers into groups. 
Table 1. Cluster mean, standard deviation, and F-ratio from an analysis of variance between clusters for each social or attitudinal variable within each cluster group of ranchers.

\begin{tabular}{|c|c|c|c|c|c|c|c|c|}
\hline $\begin{array}{l}\text { Cluster } \\
\text { Number }\end{array}$ & & $\begin{array}{l}\text { WOULD SELLI } \\
\text { RANCH }\end{array}$ & $\begin{array}{l}\text { LAND2 } \\
\text { ETHIC }\end{array}$ & $\begin{array}{l}\text { FAMILY2 } \\
\text { LIFE }\end{array}$ & $\begin{array}{l}\text { SOCIAL } \\
\text { TIES }\end{array}$ & $\begin{array}{l}\text { PROFIT2 } \\
\text { MOTIVE }\end{array}$ & $\begin{array}{c}\text { JOB }^{3} \\
\text { MOBILITY }\end{array}$ & $\begin{array}{c}\text { ASSET } \\
\text { MOBILITY }\end{array}$ \\
\hline 1 & $\begin{array}{c}\text { mean } \\
\text { sd }\end{array}$ & $\begin{array}{l}0.96 \\
0.20\end{array}$ & $\begin{array}{l}1.68 \\
0.91\end{array}$ & $\begin{array}{l}1.48 \\
0.80\end{array}$ & $\begin{array}{l}3.31 \\
0.78\end{array}$ & $\begin{array}{l}2.91 \\
1.01\end{array}$ & $\begin{array}{l}3.38 \\
0.93\end{array}$ & $\begin{array}{l}2.91 \\
1.10\end{array}$ \\
\hline 2 & $\begin{array}{c}\text { mean } \\
\text { sd }\end{array}$ & $\begin{array}{l}0.00 \\
0.00\end{array}$ & $\begin{array}{l}1.76 \\
1.01\end{array}$ & $\begin{array}{l}1.67 \\
1.00\end{array}$ & $\begin{array}{l}2.93 \\
1.08\end{array}$ & $\begin{array}{l}2.68 \\
1.12\end{array}$ & $\begin{array}{l}3.09 \\
1.11\end{array}$ & $\begin{array}{l}2.12 \\
1.04\end{array}$ \\
\hline 3 & $\begin{array}{c}\text { mean } \\
\text { sd }\end{array}$ & $\begin{array}{l}0.96 \\
0.20\end{array}$ & $\begin{array}{l}1.54 \\
0.69\end{array}$ & $\begin{array}{l}1.38 \\
0.68\end{array}$ & $\begin{array}{l}2.18 \\
0.99\end{array}$ & $\begin{array}{l}2.04 \\
1.01\end{array}$ & $\begin{array}{l}1.62 \\
0.78\end{array}$ & $\begin{array}{l}1.38 \\
0.62\end{array}$ \\
\hline 4 & $\begin{array}{c}\text { mean } \\
\text { sd }\end{array}$ & $\begin{array}{l}0.97 \\
0.18\end{array}$ & $\begin{array}{l}1.61 \\
0.84\end{array}$ & $\begin{array}{l}1.21 \\
0.55\end{array}$ & $\begin{array}{l}1.50 \\
0.50\end{array}$ & $\begin{array}{l}2.81 \\
0.89\end{array}$ & $\begin{array}{l}3.19 \\
1.07\end{array}$ & $\begin{array}{l}3.45 \\
0.78\end{array}$ \\
\hline \multicolumn{2}{|c|}{$\begin{array}{l}\text { GRAND MEAN } \\
\text { FOR ALL CLUSTERS }\end{array}$} & 0.75 & 1.65 & 1.45 & 2.62 & 2.64 & 2.87 & 2.48 \\
\hline \multicolumn{2}{|l|}{ F ratio 4} & 521.6 & 0.86 & 3.85 & 63.7 & 11.4 & 52.7 & 64.4 \\
\hline
\end{tabular}

${ }^{1}$ Response was Would Sell $=0$ and Would Not Sell $=1$.

2Response ranged from 1 to 4 with $1=$ important, $2=$ medium, $3=$ low, and $4=$ no importance for continuing in ranching.

${ }^{3} \mathrm{~A}$ response of 1 indicated mobility was difficult and an important reason that they continued in ranching, a response of 4 indicated difficulty in finding a job or in selling the ranch was not important.

«Degree of freedom 3,309.

The significance of the remaining variables showed that the constraints a rancher faces in labor and asset mobility are just as important as the social and attitude factors for continuation in ranching. Asset mobility and social ties had the largest F-ratios (Table 1) followed by job mobility, profit motivation, and the quality of family life on the ranch. The land ethic variable was not significantly different between cluster groups ( $F=0.86$ in Table 1 ), although all groups placed high or medium importance to this variable.

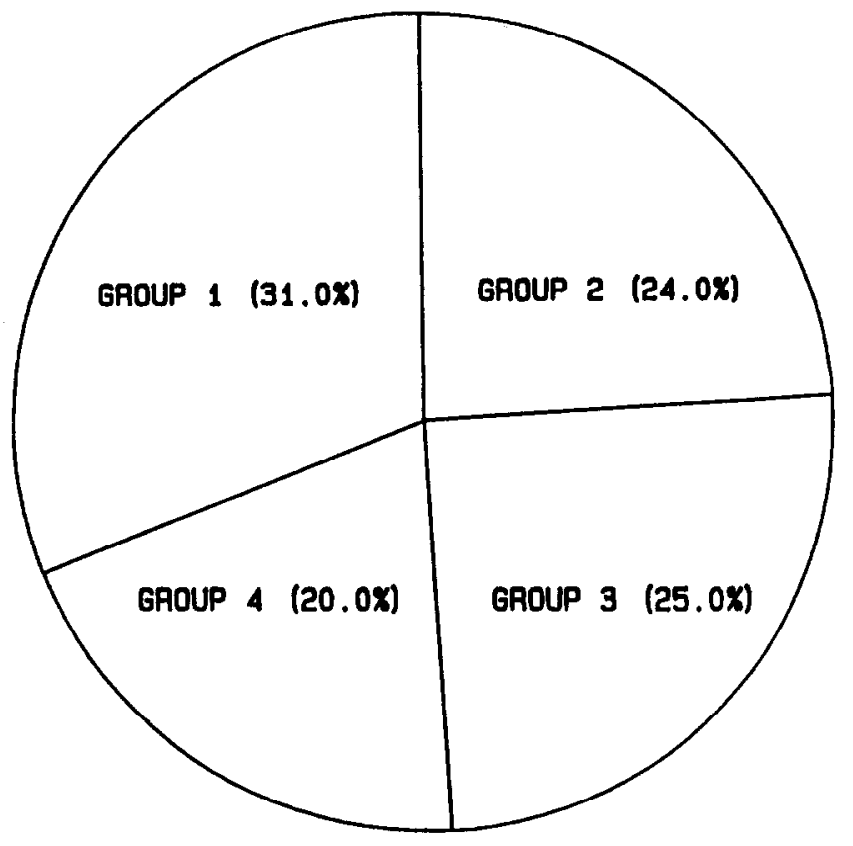

Fit. 4. The percentage of ranchers designated in each of the four cluster groups.

Beyond the ranking of significance of the variables, cluster analysis provided a description of each cluster group. Group 2 was the only cluster of ranchers that would sell their ranch at or near the current market price, although they cited the difficulty of selling ranch assets in the current market as a fairly important reason for continuing to ranch. This group placed slightly less importance on the land ethic and the desirability of ranch life for their family than did the other groups. Thus, cluster 2 ranchers were the ranchers that would be willing to sell but were otherwise similar to other ranchers regarding social values.

Group 1 ranchers are not considering selling their ranches in the current market. They placed a relatively high importance on owning a ranch and on family life. Ties to friends and relatives, and obtaining a good return on their investment were of the lowest importance of any group. Further, the opportunity to leave ranching, as indicated by the low importance placed on asset and labor mobility, was not a constraint.

Group 4 was similar to group 1, but ranchers in this group had the highest degree of asset mobility and placed the highest importance on family related matters. They found that being near friends and relatives was a very important reason for staying in ranching. This would indicate that one-half of the ranchers in Colorado (Fig. 4) have other opportunities but choose to be in ranching because of land fundamentalism and social reasons.

Groups 3 and 4 were very similar in their behavior and social attitudes. Social ties, family, emphasis on profit, and land ethic for both groups were all more important than the overall average, and exhibited only slight difference in intensity of these variables. The major difference was that ranchers in group 3 felt that the lack of other job opportunities and the difficulty in selling their ranch were important reasons why they continued in ranching. These two clusters show that, even though ranchers can realistically face differing mobility of ranch assets and labor, this does not affect their desire to continue in ranching as long as the ranch provides the quality of family life, some financial return, and social ties.

Groups were analyzed with respect to ranch size and degree on dependency on federal forage during the summer. Ranch size was based on total animal units (AU's) and averaged 335 AU's. Ranch size across the four cluster groups was not significantly different nor was the percent contribution of federal forage to summer grazing.

\section{Conclusions}

Most Colorado cattle ranchers using federal forage in the summer were not willing to sell their ranches at 1983 prices. They valued owning a ranch regardless of other attitudes and also valued raising a family on a ranch. While the profit motive was significant in classifying ranchers, job and asset mobility better differentiated ranchers into groups. 
Those who had the highest difficulty in obtaining other jobs or selling their ranches attached the highest importance to profit as the reason that they are in ranching. Perhaps because of the mobility constraints, these ranchers are more aware that a good return on investment is important to their survival even though they value ranching as a way of life.

Ranchers who did not consider job and asset mobility as important reasons for being in ranching (groups 1 and 4) ranked profit lower than the other groups. These individuals are likely to be the last to sell their ranches.

Ranchers who were willing to sell their ranches listed difficulty in selling them as a moderate reason for being in ranching, but were not as profit oriented as those with the lowest labor and asset mobility. This would suggest that even though those who would sell at market prices thought that they would have difficulty in doing so. Thus, although economic factors may cause some to quit cattle ranching, the majority value ranching as a way of life.

\section{Literature Cited}

Dixon, W.J., ed. 1981. BMDP statistical software 1981. Univ. California Press, Berkeley.

Johnoon, R.A., and O.W. Wichern. 1982. Applied multivariate statistical analysis. Prentice-Hall Inc., Englewood Cliffs, NJ.

MeKean, J.R., J.G. Hof, E.T. Bartlett, and R.G. Taylor. 1986. Contingent value estimates for existing federal grazing. Colorado State Univ. Agr. Exp. Sta., Fort Collins. Tech. Bull. TB86-1.

Smith, A.H. 1971. A socioeconomic analysis of the goals and attitudes of Arizona cattle ranchers. Unpub. Ph.D. Diss. Univ. of Ariz., Tucson.

Smith, A.H., and W.E. Martin. 1972. Socioeconomic behavior of cattle ranchers with implications for rural community development in the West. Amer. J. Agr. Econ. 54:217-225.

Water Rewources Councll. 1979. Procedures for evaluation of national economic development benefits and costs in water resources planning, final rule. Fed. Reg. 8 CFR Part 713, Vol. 44, No. 242, Rules and Regulations. p. 72892-72976.

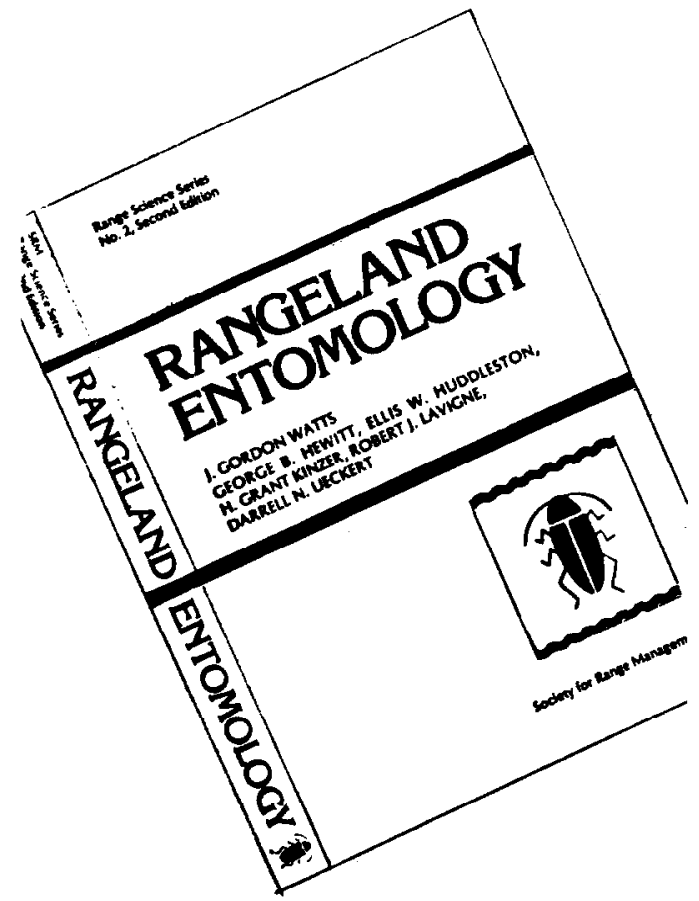

NOWHERE

will you find more information in one place on this increasingly important subject. A greater variety of uses for rangeland, a growing world population, plus deeper concerns for the environment make knowledge about insect grazers of rangeland ever more critical. Written to be understood by the average reader, RANGELAND ENTOMOLOGY still contains the extensive bibliography, lists of both common and scientific names, and suggestions for needed research to make it a valuable addition to the scientist's library. The second edition, edited by J. Gordon Watts, has been expanded to over 300 pages with state-of-the-art information on insect friends and foes of rangeland plants and animals and the role of integrated pest management.

Range Science Series No. 2, Second Edition, will be available from the Society for Range Management by February 1990. 